\title{
Observed Risk Factors and the Prevalence of Potential Oral Malignant Lesions among a North Indian Population
}

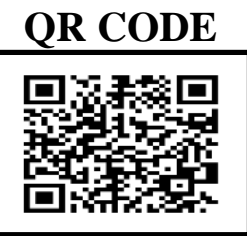

\section{VASUDA BHAGAT*1, MEHTAB SINGH BHAGAT ${ }^{2}$}

INTRODUCTION: The menace of oral cancer has become a public health concern and its prevalence is increasing with every passing day, making it the sixth most common cancer across the globe.

AIM: To evaluate the prevalence and risk factors for potential oral malignant lesions in a middle aged north Indian population.

MATERIALS AND METHODS: Adopting a Cross-sectional study design, this study examined a total of 944 participants in the Delhi-NCR region and males formed a majority of the population $(569,60.3 \%)$. Data was collected using a pre-tested and pre-validated questionnaire. Descriptive statistics was applied and the chi-squared test (for qualitative data) and independent samples t-test(for quantitative data) was applied to find out statistical differences (Using SPSS 21.0), if any.

RESULTS: It was reported that $201(21.29 \%)$ of the study population suffered from oral malignant lesions, and the most prevalent lesion was OSMF [115, 12.18\%] followed by leukoplakia [49, 5.19\%]. The prevalence of oral malignant lesions among males was found to be higher(18.97\%) as compared to females. A significant difference was found between the oral lesions and tobacco ever and never chewers ( $<<0.001)$.

CONCLUSION: The results indicate a need to focus tobacco cessation programmes in the population of Delhi-NCR and reinforce it from time to time to reduce the burden of such Oral Malignant Lesions.

KEYWORDS: Leukoplakia, OSMF, Oral Malignant Lesions, Tobacco

\section{INTRODUCTION}

Although similar to human skin, the oral mucosa faces exposure to different kinds of complex environments due the habits and dietary patterns of an individual. ${ }^{1}$ This exposure to various kinds of substances have the potential to harm the integrity of the oral mucosa which can cause a change in colour, shape, size and consistency leading to various disorders and/or Oral Mucosal Lesions (OMLs) in an individual.

Although a majority of OMLs are benign in nature and require no specialized treatment, a few lesions might be of concern as they may have certain pathological changes that can transform them into potentially malignant disorder. ${ }^{2}$

The various reasons for the occurrence of such lesions ranges from infections (bacterial, viral, fungal) to local trauma and/or irritation (e.g. traumatic keratosis, irritational fibroma, burns), along with systemic diseases or excessive consumption of tobacco, betel quid and also alcohol. ${ }^{3}$ Such lesions have the capacity to significantly impact one's quality of life and increase the burden of these diseases in a society/nation. ${ }^{4}$ Treatment of such lesions add an extra financial burden on the individual in addition to regular visits to the treatment centre wasting one's precious time and effort.
The use of tobacco products has been considered as a prime etiological factor for the formation of OMLs and its easy availability and cheap pricing leads to its increased consumption across the globe. Use of tobacco products among individuals can be due to a variety of reasons which includes use for recreational purposes, peer pressure, to relieve stress, etc. In Asians population, the cause for a steep rise of such OMLs is due to cigarette smoking, excess alcohol intake, and areca quid chewing. 5 Various others factors documented by various researchers across of the globe are Body Mass Index and diabetes coupled with various dietary preferences (low vegetable inclusion, lesser fruit incorporation). ${ }^{6}$

The prevalence of oral mucosal diseases varies from $10.8 \%-81.3 \%$ in different populations ${ }^{7}$, with malignant tumors, representing only a minor percentage among these lesions.

Keeping in mind the harmful effects of various etiological factors in formation of OMLs and its capability to increase the burden of disease significantly in a society, the present study was undertaken with an aim to record and evaluate the Prevalence and risk factors for Potential oral malignant disorders in a 
middle aged North Indian population.

\section{MATERIALS AND METHODS}

This study adopted a cross -sectional designed and data was collected in the region of Delhi-NCR through a pretested and pre-validated proforma (adopted \& modified from Kumar $\mathrm{S}$ et $\mathrm{al}^{8}$ ) to record data of various patients visiting various oral health screening/ treatment camps. The camps were organized during the months of March 2018- February 2019 (12 months duration) after an ethical clearance was obtained from the institutional review board. It was kept in mind that the participants (aged $>18$ years) were duly explained about the study objectives and a written consent was obtained from them after they were assured of the confidentiality of the data obtained. Also they were informed that their data recorded could be used for research purposed, however, their individual identities shall remain masked.

The sample size was selected through the prevalence of OMLs obtained in the pilot study done to check for the feasibility of the study. It was observed that approximately $29.4 \%$ of the total screened population (125 in number) were having some kind of OML present in them. This prevalence rate was amenable to statistical analysis and using statistical deductions done by a certified statistician, the sample was found to be 783 . However, we aimed to include $>800$ people in the study to account for loss of people/data.

The inclusion criteria was above 18 years as they could legally give consent on participation in the study. Exclusion criteria included participants who did not give their consent to be a part of the study. The part of the proforma first contained data regarding socio demographic profile, socio economic status (based on Kuppuswamy scale), age and gender of the participants. A total of 944 participants were included in the study and the data obtained from them was analysed.

The second sub-section focused on the oral hygiene, the preventive measures taken to maintain it and recorded the adverse oral habits with its detailed noting of the quantified amount along with its quantity consumed. was registered. The third subsection emphasised primarily on the adverse oral habits present in the study population which majorly included data on tobacco chewing, areca nut use, and alcohol consumption. The participants were divided into ever chewers and never chewers with respect to smokeless tobacco.
The examinations were carried out by two observers who had two recoding clerks by their side and all of them were duly standardized prior to the study. Descriptive statistics was applied and the chi-squared test (for qualitative data) and independent samples ttest(for quantitative data) was applied to find out statistical differences (Using SPSS Version 21.0), if any among the study population.

\section{RESULTS}

Of the total 944 participants in the study, males formed a majority of the population $(569,60.3 \%)$ and a Greater portion belonged to the middle class (35.5\%) or lower class (34.6\%) divisional percentage based on their socioeconomic status. $70.6 \%$ of the population were using a toothbrush to clean their teeth. (Table 1)

It was documented that $21.29 \%$ of the Northern Indian Population which suffered from oral malignant lesions, with the prevalence rates of OSMF being 115 (12.18\%) followed by leukoplakia in $5.19 \%$, Lichen Planus in $2.54 \%$ and lowest being erythroplakia seen in 1.37 of the study subjects (Table 2 ).

\begin{tabular}{|c|c|c|}
\hline CHARACTERISTICS & CATEGORIES & $\begin{array}{l}\text { NUMBER } \\
(\%)\end{array}$ \\
\hline \multirow[t]{2}{*}{ GENDER } & MALE & $569(60.3 \%)$ \\
\hline & FEMALE & $379(39.7 \%)$ \\
\hline \multirow[t]{3}{*}{$\begin{array}{l}\text { SOCIO ECONOMIC } \\
\text { POSITION }\end{array}$} & $\begin{array}{l}\text { UPPER } \\
\text { INCOME } \\
\text { GROUP }\end{array}$ & $376(29.8 \%)$ \\
\hline & $\begin{array}{l}\text { MIDDLE } \\
\text { INCOME } \\
\text { GROUP }\end{array}$ & $448(35.5 \%)$ \\
\hline & $\begin{array}{l}\text { LOWER } \\
\text { INCOME } \\
\text { GROUP }\end{array}$ & $436(34.6 \%)$ \\
\hline \multirow[t]{3}{*}{$\begin{array}{l}\text { BRUSHING } \\
\text { METHODOLOGY }\end{array}$} & TOOTHBRUSH & $890(70.6 \%)$ \\
\hline & FINGER & $156(12.3 \%)$ \\
\hline & $\begin{array}{c}\text { OTHER } \\
\text { DENTRIFICES }\end{array}$ & $214(16.9 \%)$ \\
\hline \multirow[t]{3}{*}{$\begin{array}{l}\text { BRUSHING } \\
\text { FREQUENCY } \\
\end{array}$} & ONCE A DAY & $887(70.3 \%)$ \\
\hline & TWICE A DAY & $235(18.6 \%)$ \\
\hline & $\begin{array}{l}\text { THRICE AND } \\
\text { MORE A DAY }\end{array}$ & $138(10.9 \%)$ \\
\hline
\end{tabular}

Table 1. Socio demographic and oral hygiene inclination and maintenance by the subjects. 


\begin{tabular}{|c|c|}
\hline PREVALENCE & $\begin{array}{c}\text { NUMBER } \\
\%\end{array}$ \\
\hline OSMF & $\begin{array}{c}115 \\
12.18 \%\end{array}$ \\
\hline LEUKOPLAKIA & $\begin{array}{c}49 \\
5.19 \%\end{array}$ \\
\hline LICHEN PLANUS & $\begin{array}{c}24 \\
2.54 \%\end{array}$ \\
\hline ERYTHROPLAKIA & $\begin{array}{c}13 \\
1.37 \%\end{array}$ \\
\hline TOTAL & $\begin{array}{c}201 \\
21.29 \%\end{array}$ \\
\hline
\end{tabular}

Table 2. Prevalence of oral probable malignant disorders in the northern Indian Population
The prevalence of oral malignant lesions among males was found to be higher(18.97\%) as compared to their female counterparts $(18,1.91 \%)$, but the difference was found to be non-significant. It was observed that in both groups, most the study population brushed once a day and this2o2

was found to be statistical significant. Tobacco consumption was another factor that was

found to have a significant statistical significance ( $\mathrm{p}<\mathrm{o.0o1}$ ) among those found with and without oral mucosal lesions. Although the results were non significant, it was observed that almost all people used a toothbrush to brush their teeth and only $02(0.2 \%)$ people reported using other methods of cleaning their teeth (Table No 3 ).

\begin{tabular}{|c|c|c|c|c|}
\hline FACTORS & CATEGORIES & $\begin{array}{l}\text { PRESENCE OF } \\
\text { OML }(\mathbf{n}, \%)\end{array}$ & $\begin{array}{l}\text { ABSENCE OF OML } \\
(\mathbf{n}, \%)\end{array}$ & p VALUE \\
\hline \multirow[t]{3}{*}{ GENDER } & Male & $183(18.97 \%)$ & $386(40.88 \%)$ & \multirow{3}{*}{0.24} \\
\hline & Female & $18(1.91 \%)$ & $361(38.24 \%)$ & \\
\hline & & 201 & 743 & \\
\hline \multirow[t]{3}{*}{$\begin{array}{c}\text { SOCIOECONOMIC } \\
\text { STATUS } \\
\end{array}$} & Upperclass & $44(21.9 \%)$ & $286(38.5 \%)$ & \multirow{3}{*}{0.375} \\
\hline & Middle class & $212(30.8 \%)$ & $212(28.5 \%)$ & \\
\hline & Lower class & $245(47 \cdot 3 \%)$ & $245(33.0 \%)$ & \\
\hline \multirow[t]{3}{*}{$\begin{array}{l}\text { CLEANING } \\
\text { METHOD } \\
\end{array}$} & Tooth brush & $193(96.1 \%)$ & $739(99.5 \%)$ & \multirow[t]{3}{*}{0.481} \\
\hline & Finger & $07(3.48 \%)$ & $03(0.40 \%)$ & \\
\hline & Others & $01(0.41 \%)$ & $01(0.1 \%)$ & \\
\hline \multirow[t]{3}{*}{$\begin{array}{l}\text { BRUSHING } \\
\text { FREQUENCY } \\
\end{array}$} & Once & $188(93 \cdot 53 \%)$ & $701(94 \cdot 3 \%)$ & \multirow[t]{3}{*}{$0.01^{*}$} \\
\hline & Twice & $13(6.47 \%)$ & $40(5 \cdot 38 \%)$ & \\
\hline & Thrice & $\mathrm{o}(\mathrm{o} \%)$ & $02(.03 \%)$ & \\
\hline \multirow[t]{2}{*}{$\begin{array}{c}\text { ALCOHOL } \\
\text { CONSUMPTION } \\
\end{array}$} & Ever consumer & $147(71.3 \%)$ & $312(42 \%)$ & \multirow[t]{2}{*}{0.456} \\
\hline & $\begin{array}{c}\text { Never } \\
\text { consumer }\end{array}$ & $54(28.87 \%)$ & $431(58 \%)$ & \\
\hline \multirow[t]{2}{*}{ TOBACCO } & Ever consumer & $121(60.2 \%)$ & $216(27.05 \%)$ & \multirow[b]{2}{*}{$<0.001^{*}$} \\
\hline & $\begin{array}{c}\text { Never } \\
\text { consumer }\end{array}$ & $80(39.8 \%)$ & $542(72.94 \%)$ & \\
\hline
\end{tabular}

Table 3. Interrelations of sociodemographic traits, oral hygiene maintenance and adverse oral Habits with oral probable malignant disorders

\section{DISCUSSION}

The present study, with an aim to record and evaluate the prevalence and risk factors for potential oral malignant disorders in a middle aged North Indian population found varying results with $21.29 \%$ of the total screened population presenting with some kind of potential oral malignant lesion. This is in agreement with Faraz SA et al $(27.84 \%)^{8}$, higher as compared to Cebeci ARI et al. ${ }^{9}$ and lower as compared to Priya MK et al. $(42.4 \%)^{10}$ and Chung et al. ${ }^{11}(12.7 \%)$. This variance could be attributed to factors including but not limited to genetic predisposition, geographic factors, consumption of tobacco, habits etc.

Most of the population screened comprised of males $569(60.3 \%)$ and this result was supported by Kamble KA et al. $[416(70.8 \%)] .{ }^{12} \mathrm{We}$ postulate that females, 
with their busy schedules and aiming to maintain their work-home balance find very little time to attend such camps, or go out of their homes/offices and get their check-up done.

The results of the present study that from the total prevalence of total oral malignant lesions was $21.29 \%$, out of which the most prevalent lesion was OSMF [115, 12.18\%], and this percentage is higher as compared Kamble KA et al (5.96\%). ${ }^{12}$ The second most lesion found to be prevalent was leukoplakia [49, $5.19 \%]$, and this percentage is in partial agreement to Mathew AL et al. (1.59\%). ${ }^{13}$ Such variances in the prevalence of oral mucosal lesions is seen across the globe and is has been stated in the literature that males are at a higher risk of developing such potential oral malignant disorders as compared to their female counterparts (Nair et al.). ${ }^{14}$ This is attributed to the increased consumption of tobacco related products among males.

The study has certain limitations one of which is that the diagnosis of a person suffering from any potential oral malignant lesions was made on presumptive tests provided in textbooks and solely on the clinical manifestations examination. No Biopsy or confirmatory tests were conducted among the examined subjects. Another limitation is the societal pressure (i.e. social desirability bias) faced by the women as they unable to admit their adverse oral habit, leading to underreporting of data.

\section{CONCLUSION}

The results of the present study document a high prevalence of Oral Malignant disorders among the population of Delhi-NCR, thus warranting a need to provide tobacco cessation counselling from time to time so that the burden of such disorders is significantly reduced in the general population.

\section{REFERENCES}

1. Al-Gburi SM, Mudhir SH. The prevalence of the oral mucosal lesions among adult patients in Abu Ghraib city (Iraq), J Res Med Dent Sci 2018;6(5):145-8.

2. Toum SE, Cassia A, Bouchi N, Kassab I. Prevalence and Distribution of Oral Mucosal Lesions by Sex and Age Categories: A Retrospective Study of Patients Attending Lebanese School of Dentistry Int J Dent. 2018; 2018: 4030134 .
3. Sridharan G. Epidemiology, control and prevention of tobacco induced oral mucosal lesions in India. Indian J Cancer 2014; 51:80-5.

4. Triantos D. Intra-oral findings and general health conditions among institutionalized and noninstitutionalized elderly in Greece. J Oral Pathol Med 2005; 34: 577-82.

5. Hernandez BY, Zhu X, Goodman MT, Gatewood R, Mendiola P, Quinata K, et al. Betel nut chewing, oral premalignant lesions, and the oral microbiome. PLoS One. 2017; 12(2): eo172196.

6. Jain A, Sharma B. The Prevalence and Risk Factors for Potential Oral Malignant Disorders in a Middle Aged North Indian Population. Int Healthc Res J. 2019;3(3):123-7. https://doi.org/10.26440/IHRJ/0303.062 47

7. Kansky AA, Didanovic V, Dovsak T, Brzak BL, Pelivan I, Terlevic D. Epidemiology of oral mucosal lesions in Slovenia. Radiol Oncol 2018; 52(3): 263-6.

8. Faraz SA, Huda I, Nabi AT, Fraz AA, Fatima A, Singh $\mathrm{N}$. Prevalence of oral mucosal lesions/conditions in $35^{-}$ 44 years age group of adults of Patna city, Bihar, India. J Dent Specialities. 2019;7(1):23-7. http://doi.org/10.18231/j.jds.2019.005

9. Cebeci ARI, Gulsahi A, Kamburoglu K, Orhan BK, Oztas B. Prevalence and distribution of oral mucosal lesions in an adult Turkish population. Med Oral Pathol Oral Buccal 2009;14(6):E 272-7.

10. Krishna Priya M, Srinivas P, Devaki T. Evaluation of the prevalence of oral mucosal lesions in a population of eastern coast of South India. J Int Soc Prevent Communit Dent 2018;8:396-401.

11. Chung $\mathrm{CH}$, Yang $\mathrm{YH}$, Wang TY, Shieh TY, Warnakulasuriya S. Oral precancerous disorders associated with areca quid chewing, smoking, and alcohol drinking in southern Taiwan. J Oral Pathol Med 2005;34:46o-6.

12. Kamble KA, Guddad SS, Nayak AG, Suragimath A, Sanade AR. Prevalence of Oral Mucosal Lesions in Western Maharashtra: A Prospective Study. J Indian Acad Oral Med Radiol 2017;29:282-7.

13. Mathew AL, Pai KM, Sholapurkar AA, Vengal M. The prevalence of oral mucosal lesions in patients visiting a dental school in Southern India. Indian J Dent Res 2008;19:99-103

14. Nair DR, Pruthy R, Pawar U, Chaturvedi P. Oral cancer: Premalignant conditions and screening - an update. J Can Res Ther 2012;8, Suppl S2:57-66. 
Source of support: Nil, Conflict of interest: None declared

Cite this article as:

Bhagat V, Bhagat MS. Observed Risk Factors and the Prevalence of Potential Oral Malignant

Lesions among a North Indian Population. Int Healthc Res J. 2019;3(6):201-205.

https://doi.org/10.26440/IHRJ/0306.09274

\section{AUTHOR AFFILIATIONS:}

1. PG Student (Department of Oral Medicine and Radiology), DJ College of Dental Sciences and Research, Modinagar

[(ORCID ID: https://orcid.org/oooo-ooo1-8344-4771), (Corresponding Author)]

2. MBBS, Medical Officer, Government of Jammu and Kashmir, India

Contact corresponding author at: vasudhabhagat1991[at]gmail[dot]com 